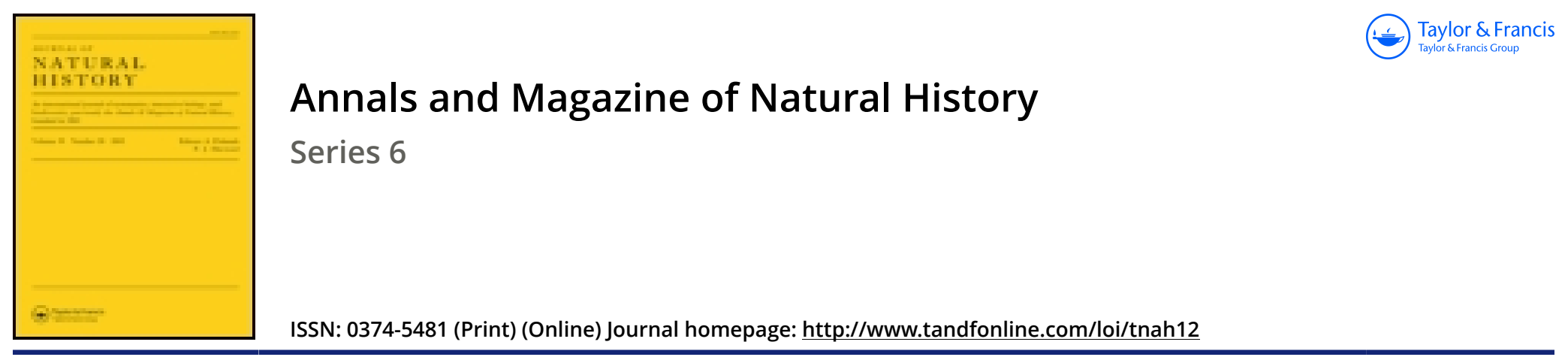

\title{
II.-On some new or little-known fishes obtained by Dr. J. W. Evans and Mr. Spencer Moore during their recent expedition to the province of Matto Grosso, Brazil
}

\section{G.A. Boulenger}

To cite this article: G.A. Boulenger (1892) II.-On some new or little-known fishes obtained by Dr. J. W. Evans and Mr. Spencer Moore during their recent expedition to the province of Matto Grosso, Brazil , Annals and Magazine of Natural History, 10:55, 9-12, DOI: 10.1080/00222939208677368

To link to this article: http://dx.doi.org/10.1080/00222939208677368

\section{曲 Published online: 02 Oct 2009.}

Submit your article to this journal ए

\section{Џ Article views: 4}

View related articles $\sqsubset$ 
II.-On some new or little-known Fishes oblained by Dr. J. W. Evans and Mr. Spencer Moore during their recent Expedition to the Province of Matto Grosso, Brazil. By G. A. Boulenger.

\section{[Plates I. \& II.]}

\section{Plecostonus pantherinus, Kner.}

Nothing could be more misleading than a division of the fishes of the genus Plecostomus according to the presence or absence of granular plates on the belly. Among the numerous specimens of $P$. bicirrhosus in the British Museurn there are some with the belly partly or entirely naked (the latter being young) which are not to be otherwise distinguished from the typical form. Thus, in three specimens (one halfgrown and two young) from British Guiana the belly is naked in one young, partly naked in the other, entirely granulate in the larger specimen. It is therefore very probable that $P$. seminudus, Eigenmann, will turn out to be merely an individual variation of $P$. bicirrhosus. With regard to the specimens which I refer to Kner's $P$. pantherinus, described from a single young specimen from the Rio Guapore, the much larger eye distinguishes them at once from $P$. bicirrhosus, their nearest ally; in Kner's specimen, 3 inches long, the eye measures one fourth the length of the head, whereas it measures only one fifth or one sixth in $P$. bicirrhosus of similar size. In the adult $P$. pantherinus the diameter of the cye is one fifth the length of the head, against one seventh or one eighth in $P$. bicirrhosus. The head is besides larger in proportion to the body in the former than in the latter.

Two specimens were obtained by Dr. Evans in the River Jangada, close to Jangada village; the larger measures 200 millim. (to the end of the middle caudal rays), the smaller 170 .

Form stout. Head as long as broad, one third total length (without caudal); snout rounded, with a small naked space at its extremity; an obtuse ridge from the upper angle of the orbit to below the nostril, the sides of the head below it being slightly concave; an obtuse ridge on the occiput and another on each side behind the eye; interoperculum with small spines. Diameter of orbit one fifth length of head, one third length of snout, three fifths to one half interorbital width, and equal to its distance from the posterior border of the head. Labial fold moderate, papillose, not or but slightly notched; barbel short. Dorsal 17, the first ray as long as or 
a little longer than the head. Anal 5. Pectoral I 5, nearly as long as the head, and extending beyond the base of the ventral. Ventral I 5. Lower candal lobe longer than upper. Scales $25 \frac{2}{2}$; lateral line 25 . Breast and belly partly naked; in the smaller specimen the anterior portion of the belly is covered with granular plates extending right across, in the larger specimen these granulations are confined to the sides and a median strip; 12 scales between the anal and caudal fins. Dark olive-brown, with rather indistinct round black spots, which are smaller and closer together on the head.

\section{Plecostomus cochliodon, Kner.}

Of this remarkable fish, of which, like the preceding, no other but the type, preserved in the Vienna Museum, was hitherto known, a single specimen was obtained by Dr. Evans at Jangada. It measures 180 millim. Its fins are unfortunately much damaged. In every respect it agrees with Kner's description. Lateral line 28.

The difference in the dentition being merely one of degree, and the fish agreeing in other respects so closely with the other species of Plecostomus, I doubt whether it is advisable to separate it as a distinct genus (Cochliodon).

\section{Loricaria Evansii, sp. n. (Plate I.)}

Teeth well developed in both jaws. Head a little longer than broad, one fourth total length (without caudal); snout obtusely pointed, with long bristles on the sides; three short keels on the back of the head; postorbital notch scarcely distinct; diameter of orbit one sixth length of head, two sevenths length of snout, and two thirds interorbital space, which is concave. Labial fold much developed, notched, papillose, and with long cirrhi. Dorsal I 7, the first ray two sevenths length of head, and just above the base of ventrals. Anal I 5. Pectoral I 6, a little shorter than head, extending to base of ventrals. Ventral I 5, as long as pectoral, reaching anal. Upper caudal ray produced in a long filament, half as long as head and body. Lateral scutes 29, with two spinose ridges meeting on the 19th; nuchal scutes with spinose keels; 20 scutes between dorsal and caudal, 17 between anal and caudal; breast and belly naked, but rough with minute spines; a series of seven or eight shields between pectoral and ventral on each side of the thorax. Olive-brown above; a dark band across the nape, and four others between the dorsal and caudal fins; fins with black spots.

Total length 205 millim. 
A single specimen from Jangada.

This fish is evidently very closely allied to $L$. nudiventris, known from a single specimen from the Rio San Francisco, described by Cuvier and Valenciennes. It differs, however, in having seven or eight shields on each side of the lower surface, between the pectoral and ventral fins, instead of four.

\section{Tetragonopterus Moorii, sp. n. (PI. II. fig. 1.)}

Length of head $3 \frac{3}{4}$ times in total length (without caudal), depth of body $2 \frac{3}{4}$. Maxillary toothless, extending to below the centre of the eye; diameter of eye $\frac{1}{3}$ length of head, $1 \frac{1}{3}$ length of snout, equal to interorbital width; adipose eyelid short. Dorsal I 10, originating above base of ventrals. Anal II 28, originating a little behind the vertical of the base of the dorsal. Pectorals reaching base of ventrals, ventrals reaching origin of anal. Scales $37-38 \frac{8}{7}$; lateral line complete. A black spot behind the shoulder; a silvery lateral stripe, turning to black on the tail and extending on the caudal.

Total length 75 millim.

Two specimens were collected by Mr. Moore on the Chapala plateau.

The nearest ally of this new species appears to be T. maximus, Stdr. (alosa, Gthr.), from the Peruvian Andes, which differs in having the interorbital region wider.

\section{Brachychalcinus, gen. nov.}

Intermediate between Tetragonopterus, Cuv., and Luetkenia, Stdr. Dentition as in the former, viz. two præmaxillary and one mandibular row of tri- or quinquecuspid teeth; body elevated, with sharp ventral edge. Differing from both in having a movable spine, directed forwards, in front of the dorsal fin.

In one of the three specimens (probably a male) this spine is hammer-shaped, its free portion forming a longer anterior and a shorter posterior branch, both of which are sharply pointed; in the two others (one of which $I$ have ascertained to be a female) the posterior process is wanting and the anterior is more developed but not spinose, spoon- or saddleshaped, rounded at the end, concave below, and fitting into a notch in the back in front of the dorsal fin. The differences in this curious arrangement will probably prove to be correlative of the sexes: In Serrasalmo the first interneural bears likewise a spine directed forwards, which is bicuspid behind and scarcely movable. 


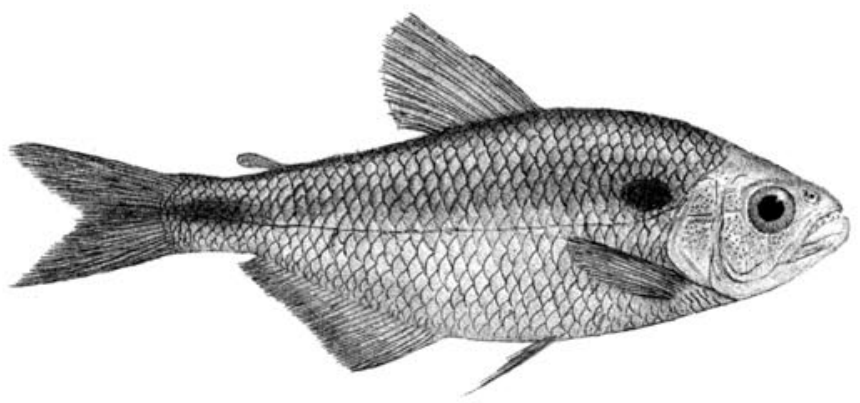

I.

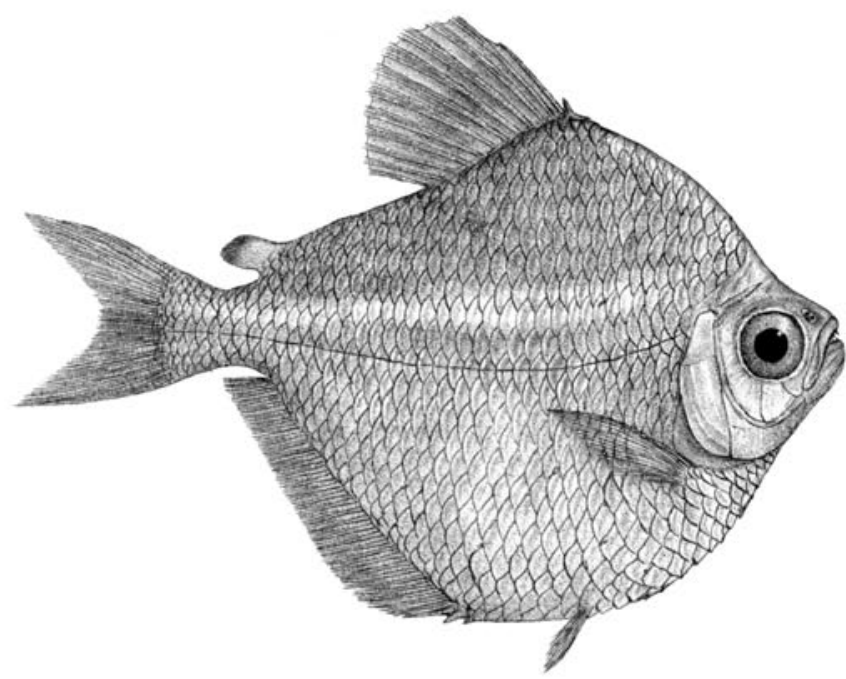


Brachychalcinus retrospina, sp. n. (Pl. II. fig. 2.)

Length of head 4 to $4 \frac{1}{3}$ times in total length (without caudal), depth of body $1 \frac{1}{3}$ to $1 \frac{1}{2}$. Maxillary toothless, nearly vertical, not extending beyond the anterior border of the eye; diameter of eye half length of head, once and two thirds length of snout, equal to interorbital space; dorsal profile ascending abruptly from above centre of eye ; a very short adipose eyelid in front. Dorsal I 11, just behind vertical of base of ventrals. Adipose fin well developed. Anal II 31-34. Pectorals slightly shorter than head, not quite reaching ventrals. Latter small, I 6 . Scales $33-35 \frac{9-10}{10-11}$; lateral line complete. A silvery lateral stripe; fins speckled with black, adipose black-edged.

Total length 80 millim.

Three specimens, from Santa Cruz.

I seize this opportunity to point out that Pseudocorynopoma Dorice, Perugia, Ann. Mus. Genova, (2) x. 1891, p. 646, fig., and Bergia altipinnis, Steindachner, Anz. Ak. Wien, 1891, p. 173, and SB. Ak. Wien, C. i. 1891, p. 366, pl. ii. fig. 2, are identical. Perugia's description (Ápril) has priority over Steindachner's (July).

The other species represented in Messrs. Moore and Evans's collection are the following :-

Acara viridis, Heck. Corumba.

Pimelodus, sp. (young). Chapala Plateau.

Macrodon trahira, Bl. Schn. Corumba.

Erythrinus unitceniatus, Spix. Corumba.

Pyrrhulina semifasciata, stdr. Corumba.

Leporinus megalepis, Gthr. Santa Cruz.

Tetragonopterus orbicularis, C. \& V. Santa Cruz.

_lacustris, Rhdt. Corumba.

- rivularis, Ltk. Chapala Plateau.

Chalcinus paranensis, Gthr. Corumba.

Xiphorhamphus ferox, (Ythr. Santa Cruz.

\section{EXPLANATION OF THE PLATES.}

\section{Plate I.}

Loricaria Evansii, $\frac{4}{5}$ nat. size.

Plate II.

Fig. 1. Tetragonopterus Moorn.

Fig. 2. Lrachychalcinus retrospina. 